\title{
INFLUENCE OF MIXTURE DESIGN, AGE, AND COOLING REGIME ON POST- FIRE MECHANICAL PROPERTIES OF LIGHTWEIGHT SELF-COMPACTED CONCRETE
}

Scientific paper

\section{Ana Romić}

(Received: 30 January 2020; accepted: 19 June 2020)

mag.ing.aedif.

Corresponding author: ana.romic93@gmail.com

Sandra Juradin

University of Split, Faculty of Civil Engineering, Architecture and Geodesy, Full Professor

Ivica Boko

University of Split, Faculty of Civil Engineering, Architecture and Geodesy, Full Professor

Neno Torić

University of Split, Faculty of Civil Engineering, Architecture and Geodesy, Associate Professor

\begin{abstract}
The post-fire mechanical properties of concrete represent an important set of parameters in the analysis of structural behavior after the occurrence of a fire. In this study, four mixtures of lightweight selfcompacted concrete with different fillers were tested. The tests were conducted by considering the ages of the specimens, which, in this study, were two, three, and five years old. The results show the residual mechanical properties of the specimens after they were heated to target temperatures of 300,500 , and $700{ }^{\circ} \mathrm{C}$. After exposure to high temperature, the specimens were either left to gradually cool until they reached room temperature or rapidly cooled by water. A comparative analysis was conducted on the compressive strength, mass, and dynamic modulus of elasticity of the specimens using the codified residual values given in EN 19941 2.
\end{abstract}

Keywords: Self-compacting lightweight concrete, concrete fillers, fire, mechanical properties, age of concrete, cooling regime, residual properties 
Influence of mixture design, age, and cooling regime on post-fire mechanical properties of lightweight self-compacted concrete

\section{INTRODUCTION}

Concrete, as one of the most frequently used building materials, is considered to have a high probability of being subjected to high temperatures during the life span of a structure. Its low thermal conductivity and reduced ignition propensity with no toxic flatulence makes it a heterogeneous and isotropic material that is characterized with the highest class of fire resistance. In addition, exposure to high temperatures can cause significant changes in its chemical and physical properties, resulting in the chemical decomposition of the concrete matrix, i.e., deterioration of properties, such as compressive strength and modulus of elasticity, as well as weight loss and color change. The dehydration of cement paste and discordant thermal expansions of mortar and aggregates weaken the bonds between those two components, especially in the interface zone. Vapor is produced when water inside the concrete is heated, which creates pressure in the concrete; this is the main cause of the explosive spalling mechanism. Fire-induced spalling is a nonstructural phenomenon that causes pieces of hardened concrete to explosively dislodge or fall-off the heated surface [1].

The effect of elevated temperature depends on concrete composition and construction characteristics; therefore, it is important to satisfy three fire-safety requirements: integrity, insulation, and structural resistance. Because of the changing values of the residual mechanical properties at high temperatures, many researchers have focused on various materials and combinations to develop a material with better high-temperature resistivity during and after a fire event. The term "residual properties" indicates the properties of a material after it has been exposed to fire and cooled to room or atmospheric temperature [2]. In general, the test results of concrete exposed to elevated temperatures are highly dependent on conditions before testing, different heating procedures, and cooling regimes.

Temperature has a significant impact on the ultimate limit state of concrete fracture, which is determined by the compressive strength of concrete. Therefore, the evaluation of residual compressive strength of concrete after different fire exposure events is important for studying its impact on the load-bearing capacity of concrete.

Previous studies have showed that the compressive strength decreases with increasing temperature owing to the decomposition of the C-S-H element in concrete. Heating normal-strength concrete up to $600{ }^{\circ} \mathrm{C}$ damages the radical concrete matrix, and therefore concrete cannot be considered as a reliable structural material beyond that temperature [3]. Furthermore, higher values of residual strength are generally expected for normal concrete with higher initial compressive strength. Compared with normal concrete, high-performance concrete (HPC) is more temperature sensitive, with more pronounced brittle failure and more rapid loss of mechanical properties. HPC with silica fumes (SFs), as partial cement replacement, showed an increase in residual compressive strength at temperatures between 100 and $400{ }^{\circ} \mathrm{C}$. This is mainly because of the interaction between silica flour particles and lime [4]. As temperature increases, the decrease in the HPC strength (and modulus of elasticity) is more pronounced compared with those of normal-strength concrete and regular HPC. The first reduction in compressive strength has been observed at approximately $300{ }^{\circ} \mathrm{C}$. When the critical temperature reaches approximately $600^{\circ} \mathrm{C}$, the matrix weakens and the binder property is lost [5]. The compressive strength decreases owing to the occurrence of microstructural damage (crystallization) and the structure of the hydrated phase changes from an amorphous form to a characteristic crystal. Temperature values of up to $900{ }^{\circ} \mathrm{C}$ result in serious deterioration of the concrete. The effect of coarse aggregate content on the residual compressive strength was found to be negligible. Furthermore, cement dosage was shown to only slightly influence the relative residual compressive strength. The admixtures, such as fly ash, palm-oil fuel ash, and rice-husk ash, which are used as replacements of cement decrease the compressive strength, modulus of elasticity, and tensile strength of the concretes at elevated temperatures [5]. The partial rehydration of cement paste after a certain period from fire exposure $(96 \mathrm{~h}$ ) has a higher positive impact on the compressive strength of concrete, while its temperature expansion is responsible for the reduction in the modulus of elasticity [2]. Therefore, it is essential to consider curing and cooling methods as well as moisture conditions after exposure to high temperatures. The recovery of mechanical properties is inversely proportional to temperature and is rapid after the specimens are rehydrated [4]. The rapid cooling and longer curing time of specimens result in the deterioration of the structure quality and severe loss in strength. Air cooling exhibits superior performance over water spraying, thus maintaining higher residual properties [4]. Although high temperatures $\left(800{ }^{\circ} \mathrm{C}\right)$ induce more cracks, quenching in water allows further cement hydration (rehydration). The cooling effect rectifies the damage caused by microcracks and supports subsequent strength recovery of concrete [5] relative to water spraying. The higher the absolute value of

Romić, A, Juradin, S, Boko, I, Torić, N 
Influence of mixture design, age, and cooling regime on post-fire mechanical properties of lightweight self-compacted concrete

the temperature gradient, the more the heat is transferred close to the surface [6]. The temperature decreases more sharply to room temperature when specimens are cooled in an ambient environment compared to those cooled inside a furnace; this is because of the effects of convection heat transfer and higher temperature gradient. Lower surrounding temperatures cause the specimens to cool faster. When cooling the specimens in the furnace, more hardened cement is dehydrated, resulting in the further loss of strength but a much shorter crack length. Furthermore, the furnace-cooled specimens have higher potency of rehydration during the post-firecuring process, because of greater provision of reactants and longer temperature exposure. In addition, their recured compressive strength is higher. Specimens cooled in ambient air have more fragile aggregates than those cooled in the furnace.

Lightweight concrete (LWC) has a better interfacial transition zone; this indicates that its aggregate shows higher stability and the concrete has higher temperature resistance than other concrete types [7]. A negative attribute of LWC is its increased risk of explosive spalling if exposed to hydrocarbon fire. Similar to normal concrete and HPC, partial rehydration (relative humidity) may influence the overall strength reduction of LWC.

In this study, the relationship between weight loss and maximum temperature was nonlinear regardless of the binder material type, while the mass loss increased with the increasing temperature of thermal exposure. The concrete also suffered noticeable color changes. Therefore, it can be concluded that the compressive strength, mass loss, and elasticity modulus are influenced by temperature increase, duration of temperature exposure, cooling regimes, and curing (re-curing) environment.

\section{CONCRETE TYPES AND TEST METHODS}

\subsection{Mix designs and curing conditions}

The aim of this experimental study was to analyze the effect of age and mix design of concrete specimens on the residual mechanical properties of a structure after its exposure to fire. The specimens were two-, three-, and five-year old at the start of the study. Their residual properties were determined after they were slowly cooled in a furnace and rapidly cooled by water. In this study, four mix designs were examined. Table 1 shows the concrete compositions; the same type of Portland cement (CEM I 42.5 R) was used for the preparation of all mixtures. The expanded clay lightweight aggregate was used in two fractions: 0-2 and 4-8 $\mathrm{mm}$. A liquid poly-carboxylic-ether superplasticizer $\left(1.06 \mathrm{~kg} / \mathrm{dm}^{3}\right)$ was used for all sample series, along with four types of fillers: recycled old concrete (Blaine specific area is $7891 \mathrm{~cm}^{2} / \mathrm{g}$ and density is $2.45 \mathrm{~g} / \mathrm{cm}^{3}$ ), microsilica (Blaine specific area is $\sim 20000 \mathrm{~cm}^{2} / \mathrm{g}$ and density is $2.3 \mathrm{~g} / \mathrm{cm}^{3}$ ), metakaolin (Blaine specific area is $\sim 22000 \mathrm{~cm}^{2} / \mathrm{g}$ and density is 2.3 $\mathrm{g} / \mathrm{cm}^{3}$ ), and ground clay brick (Blaine specific area is $4992 \mathrm{~cm}^{2} / \mathrm{g}$ and density is $2.6 \mathrm{~g} / \mathrm{cm}^{3}$ ). The total quantities of binders in the concrete were 450 and $455 \mathrm{~kg} / \mathrm{m}^{3}$, respectively.

Table 1 Concrete mix designs

\begin{tabular}{ccccccccccc}
\multicolumn{8}{c}{ Mix Cement Water w/c Recycled concrete Microsilica Metakaolin Ground clay Superplasticizer } & Aggregate $[\mathrm{mm}]$ \\
& {$[\mathrm{kg}]$} & {$[\mathrm{kg}]$} & & {$[\mathrm{kg}]$} & {$[\mathrm{kg}]$} & {$[\mathrm{kg}]$} & {$[\mathrm{kg}]$} & {$[\mathrm{kg}]$} & $\mathbf{0 - 2}$ & $\mathbf{4 - 8}$ \\
\hline$R C$ & 400 & 200 & 0.5 & 50 & - & - & - & 4.8 & 516.1 & 531.8 \\
MS & 380 & 220 & 0.42 & - & 75 & - & - & 5.46 & 544.2 & 560.7 \\
MK & 380 & 190 & 0.5 & - & - & 75 & - & 5.46 & 508.2 & 523.6 \\
GC & 400 & 200 & 0.5 & - & - & - & 65 & 4.8 & 498.2 & 513.3 \\
\hline
\end{tabular}

The Swedish Cement and Concrete Research Institute (CBI) Model was used for achieving the mix design [8], and the workability was examined with respect to fresh concrete by using the slump-flow method, visual check for stability, T500 time, and V-funnel, as shown in Table 2. 
Influence of mixture design, age, and cooling regime on post-fire mechanical properties of lightweight self-compacted concrete

Table 2 Results of slump-flow, T500, and V-funnel according to EFNARC [8] and compressive strength

\begin{tabular}{|c|c|c|c|c|c|c|c|}
\hline Mis & $\begin{array}{c}\text { Slump-flo } \\
\text { [mm] }\end{array}$ & $\begin{array}{l}\text { Class } \\
\text { (SF) }\end{array}$ & $\begin{array}{c}T 500 \\
{[\mathrm{~s}]}\end{array}$ & $\begin{array}{l}\text { Class } \\
\text { (VS) }\end{array}$ & $\begin{array}{c}\text { V-funne } \\
{[s]}\end{array}$ & $\begin{array}{l}\text { Class } \\
\text { (VF) }\end{array}$ & $\begin{array}{c}\text { Compressive strengtl } \\
{[\mathrm{MPa}]}\end{array}$ \\
\hline$R C$ & 640 & SF2 & 2.59 & VS2 & 4.69 & VF1 & 28.6 \\
\hline MS & 545 & - & 1.69 & VS1 & 6.33 & VF1 & 39.7 \\
\hline MK & 715 & SF2 & 2.22 & VS2 & 7.49 & VF1 & 45.5 \\
\hline GC & 762.5 & SF3 & 1.16 & VS1 & 6.96 & VF1 & 32.1 \\
\hline
\end{tabular}

The mixtures were cast into cubic molds with a length of $150 \mathrm{~mm}$. Furthermore, cylinders with a diameter-height ratio of $1 / 3$ (i.e., $75 \mathrm{~mm} \times 225 \mathrm{~mm}$ ) were selected for usage in accordance with RILEM requirements and previous studies [7,9]. Three cubic and a hundred cylindrical specimens were tested. After $24 \mathrm{~h}$, the specimens were removed from the molds and cured in water at $20 \pm 5^{\circ} \mathrm{C}$. The cubic specimens were cured in water for 27 days and tested according to the guidelines provided in EN 12390-3. Table 2 lists the compressive strength results obtained after 28 days. Similarly, the cylindrical specimens were cured in water for 6 days and then cured in air at $20 \pm 3^{\circ} \mathrm{C}$ and $50 \%$ relative humidity until testing.

\subsection{Test setup and instrumentation}

To obtain the target temperature, the heating process was conducted in series at temperatures of 300,500 , and $700{ }^{\circ} \mathrm{C}$. The first significant reduction in the compressive strength is known to occur at $300{ }^{\circ} \mathrm{C}[4]$; therefore, this target temperature was selected to be the first test temperature in the current study. By considering each subsequent temperature increase of $200{ }^{\circ} \mathrm{C}$, the abovementioned specified temperatures were selected. Six specimens were tested for each temperature level and concrete mixture. The heating curves of the specimens and the furnace are presented in Fig. 1.

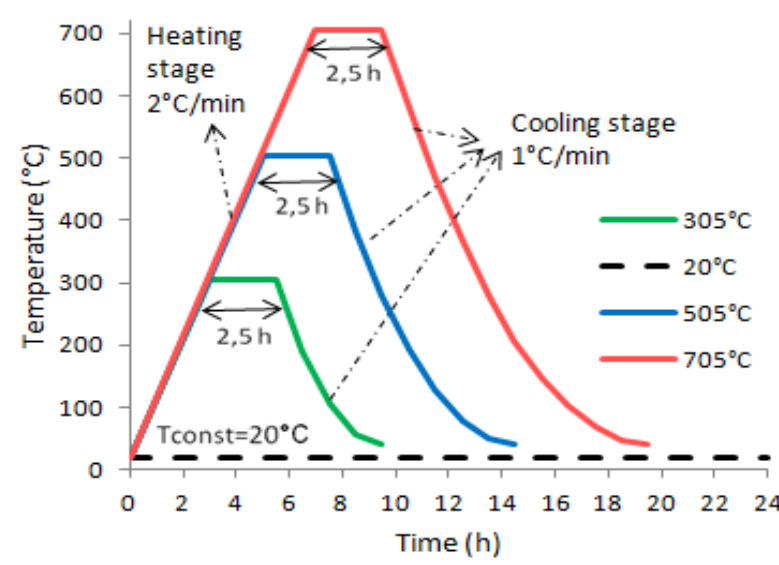

(a)

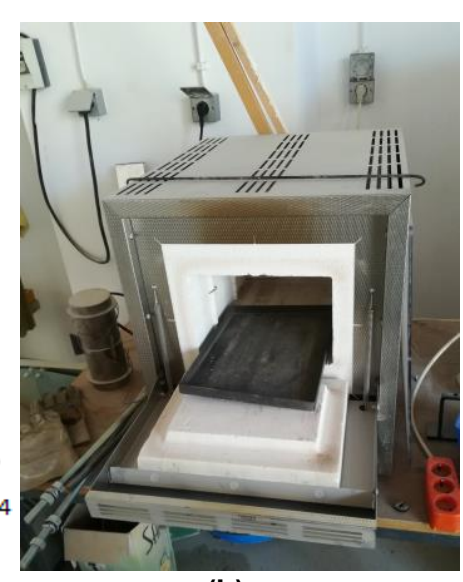

(b)

Figure 1 (a) Heating process, and (b) furnace used for heating the specimens

The specimens were prepared for testing according to the required conditions set by RILEM. The ends of the specimen should be nominally parallel, flat, and orthogonal to its central axis [9]. This preparation must be completed at least 28 days to 2 months before the testing. Considering the age testing requirement set by RILEM, specimens older than 90 days were selected [9]. Before conducting the tests, the specimens were predried to a constant mass in the oven at $100{ }^{\circ} \mathrm{C}$ for $24 \mathrm{~h}$ to remove free water. The humidity of the samples before predrying was in the $3 \%-6 \%$ interval. The dried samples were then exposed to linear heating up to their peak temperatures with a heating rate of $2{ }^{\circ} \mathrm{C} / \mathrm{min}$ up to the target temperature. The target temperature was maintained constant for over $2.5 \mathrm{~h}$ to achieve a more uniform temperature distribution in the specimen [7]. The dimensions, mass, and ultrasonic pulse velocity (UPV) of the specimens were measured at temperature around $20^{\circ} \mathrm{C}$ and after every heating stage (Figs. $2(\mathrm{a})$ and (b)). 
Influence of mixture design, age, and cooling regime on post-fire mechanical properties of lightweight self-compacted concrete

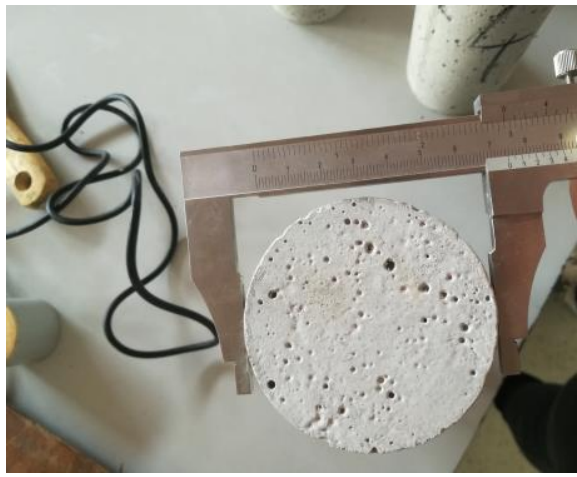

(a)

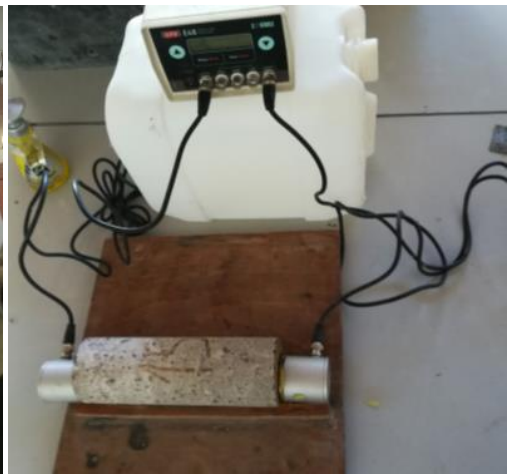

(b)

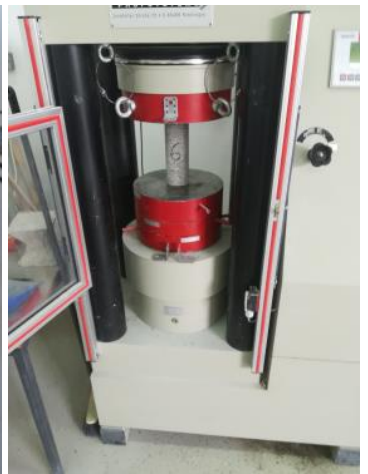

(c)

Figure 2 Test instruments: (a) dimensions, (b) ultrasonic pulse velocity, and (c) compressive test machine

After maintaining a constant target temperature, the specimens were cooled using either of the following two methods: they were (1) left to cool down in furnace until they reached room temperature (around $20^{\circ} \mathrm{C}$ ) or (2) rapidly cooled using water. Water-based cooling was performed using sprinklers under a constant pressure of 2.2 bar. Once they were cooled, the specimens were tested in a compressive-test machine with a loading rate of 0.5 $\pm 0.1 \mathrm{MPa} / \mathrm{s}$ until failure, where their compressive strength was determined, as shown in Fig. 2 (c).

The dynamic modulus of elasticity was determined by measuring the mean value of the ultrasonic pulse velocity (UPV) per diameter:

$$
E_{v}=v^{2} \cdot \rho \cdot(1+\mu) \cdot(1-2 \mu) /(1-\mu) .
$$

The mean value of Poisson's coefficient for the specimens was taken as 0.2 [8], and the mass of every specimen was measured using a digital weighing scale before and after each heating phase. Two-, three-, and five-year old tested specimens were examined.

\section{EXPERIMENTAL RESULTS AND DISCUSSIONS}

\subsection{Compressive strength}

The mean dimensionless values of post-fire compressive strength, $f_{c, T}$, are related to the mean reference compressive strength obtained after the specimens are dried at $100^{\circ} \mathrm{C}$ for $24 \mathrm{~h}$, i.e., $\mathrm{f}_{\mathrm{c}, 100 .}$. The results of the two aforementioned cooling methods with respect to the effects of the specimens' age and time required for firetesting of every mixture were compared with the values of the reduction factors provided in Eurocode 4. In Fig. 3, the gradually cooled specimens are marked with a solid line, while the dashed line represents the data of the rapidly cooled specimens. The figure shows the influence of specimen age for every concrete mixture.
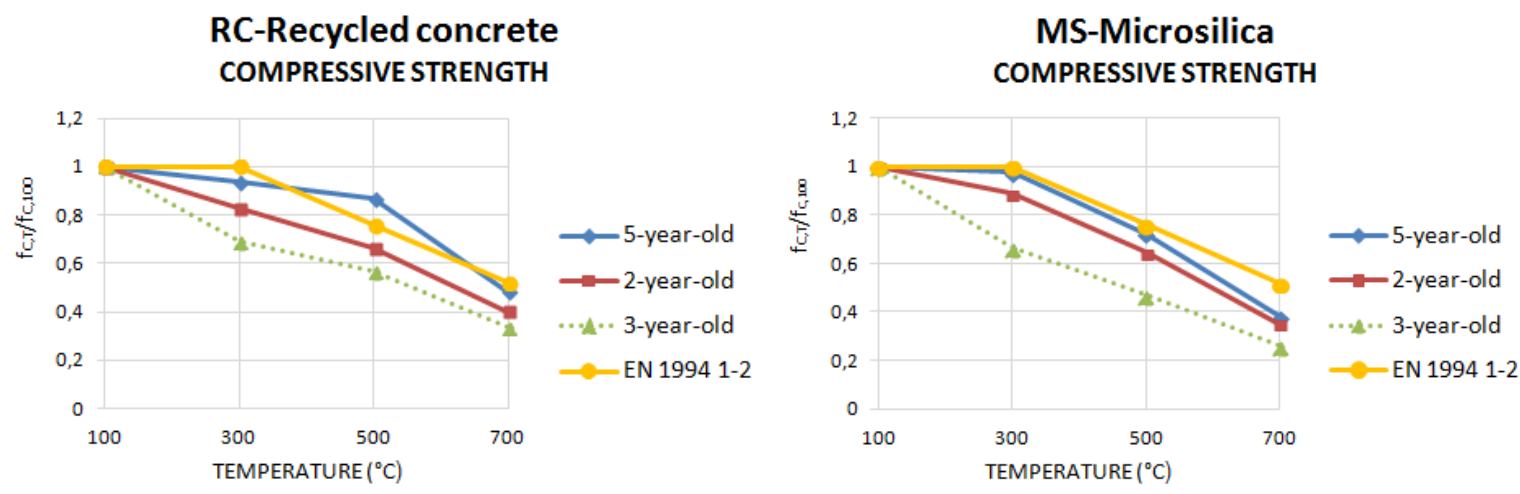
Influence of mixture design, age, and cooling regime on post-fire mechanical properties of lightweight self-compacted concrete
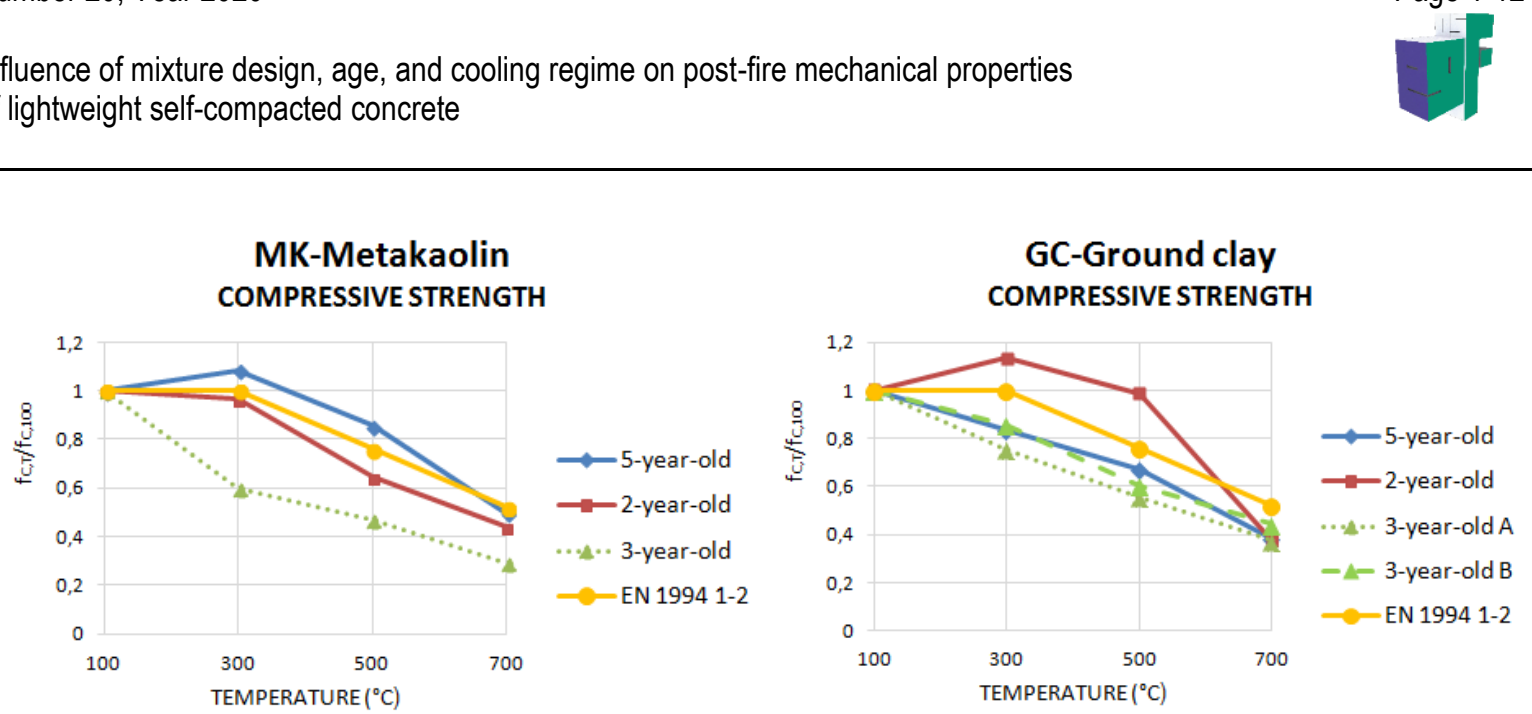

\section{Figure 3 Reduction factors for residual compressive strength of four mixtures based on the target temperature and specimen age compared with the values recommended by EN 1994 1-2}

The test series of recycled concrete show a decreasing trend of compressive strength with increasing temperature. The residual values are higher for older specimens with the highest difference range (around $20 \%$ ) at $500{ }^{\circ} \mathrm{C}$. The rapidly cooled specimens (three-year-old) showed lower values of residual compressive strength. These observations suggest that the cooling method has a significant impact on the constancy of compressive strength [4], with the largest difference within the $300-500{ }^{\circ} \mathrm{C}$ range. Generally, for both cooling methods, the specimens experience a significant loss of compressive strength after $700{ }^{\circ} \mathrm{C}$, with an average reduction of approximately $60 \%$.

Specimens with microsilica filler exhibited less difference in their residual strength with respect to specimen age. The decrease in the compressive strength of this mixture was more pronounced after $300{ }^{\circ} \mathrm{C}$. In addition, the cooling methods show similar behaviors as those for the recycled concrete. The residual compressive strength of these specimens at $700{ }^{\circ} \mathrm{C}$ is approximately $30 \%$ less than that of specimens heated at $100{ }^{\circ} \mathrm{C}$.

For the third test series, metakaolin, as a filler, exhibited a significant change in the compressive strength of concrete after gradual cooling with respect to the specimen age. Furthermore, the only differences observed included a slight increase in residual strength up to $300{ }^{\circ} \mathrm{C}$; on average, the residual strength was $10 \%$ higher than that of the series with recycled concrete. In this series, the specimen age showed a positive effect on the design mixture, and almost all the obtained results showed values greater than those of the reduction factors recommended by Eurocode 4 . This indicates that the metakaolin mixture possesses very high fire-resistance properties. Moreover, the strength of the rapidly cooled specimens was almost half that of the gradually cooled specimens.

The fourth concrete mixture with ground clay does not follow the positive trend of increase in residual compressive strength with respect to specimen age. At 300 and $500{ }^{\circ} \mathrm{C}$, the two-year-old specimen showed the highest values of compressive strength. However, at higher temperature levels, the specimen showed a very sharp drop in compressive strength. At $700{ }^{\circ} \mathrm{C}$, the strength values of the ground clay specimen were the lowest among all four mixtures. Furthermore, the test results for the five-year-old specimen were significantly lower than the other three mixtures and Eurocode-4 factors. In a previous study [10] with the same filler types, the authors had proved that finely ground brick clay can be recycled as a pozzolanic cementitious material in concrete with lower sensitivity strength. In this study, a possible cause of this poor mix performance was determined as the bleeding in fresh concrete, which resulted in a segregation phenomenon in the specimens, as shown in Fig. 4.

For the fourth test series, two compressive strengths were calculated using the rapid-cooling procedure but in a different measuring interval of $24 \mathrm{~h}$, as shown in Fig. 3, where letter A marks the specimens, the compressive strength of which was obtained immediately after cooling, while letter B marks the specimens, the residual strength of which was obtained $24 \mathrm{~h}$ after cooling. The results demonstrate higher residual property for case $\mathrm{A}$, with a difference of approximately $10 \%$. The humidity of the specimens did not have any influence on the test results. Accordingly, a repetition of the testing was not required for the whole series of specimens. 
Influence of mixture design, age, and cooling regime on post-fire mechanical properties of lightweight self-compacted concrete

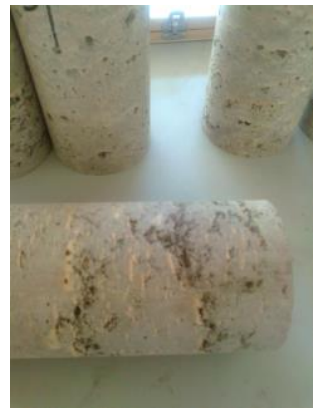

(a)

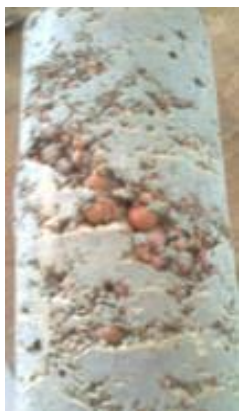

(b)

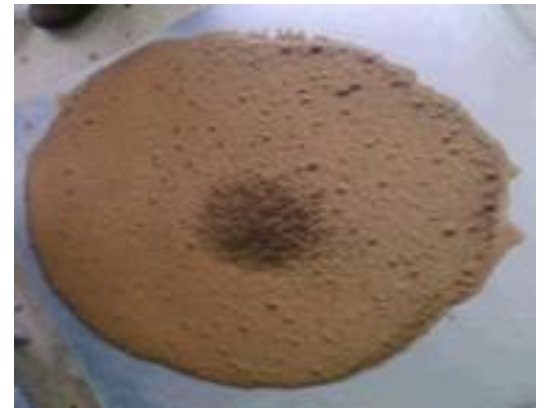

(c)

Figure 4 (a) Segregation of concrete specimens with ground clay; (b) SF method and (c) bleeding in fresh concrete [11]

To investigate the effect of the treatment method after fire exposure on the specimen strength, nine additional three-year-old specimens from the series with the metakaolin filler were also examined (Fig. 5). The first three specimens were heated up to $300^{\circ} \mathrm{C}$, rapidly cooled with water, and then dried at $100{ }^{\circ} \mathrm{C}$ for $24 \mathrm{~h}$. Their residual compressive strength was approximately $70 \%$ higher than that of the three-year-old specimens (from the same series) that were only rapidly cooled and $16 \%$ higher than the gradually cooled two-year-old specimens.

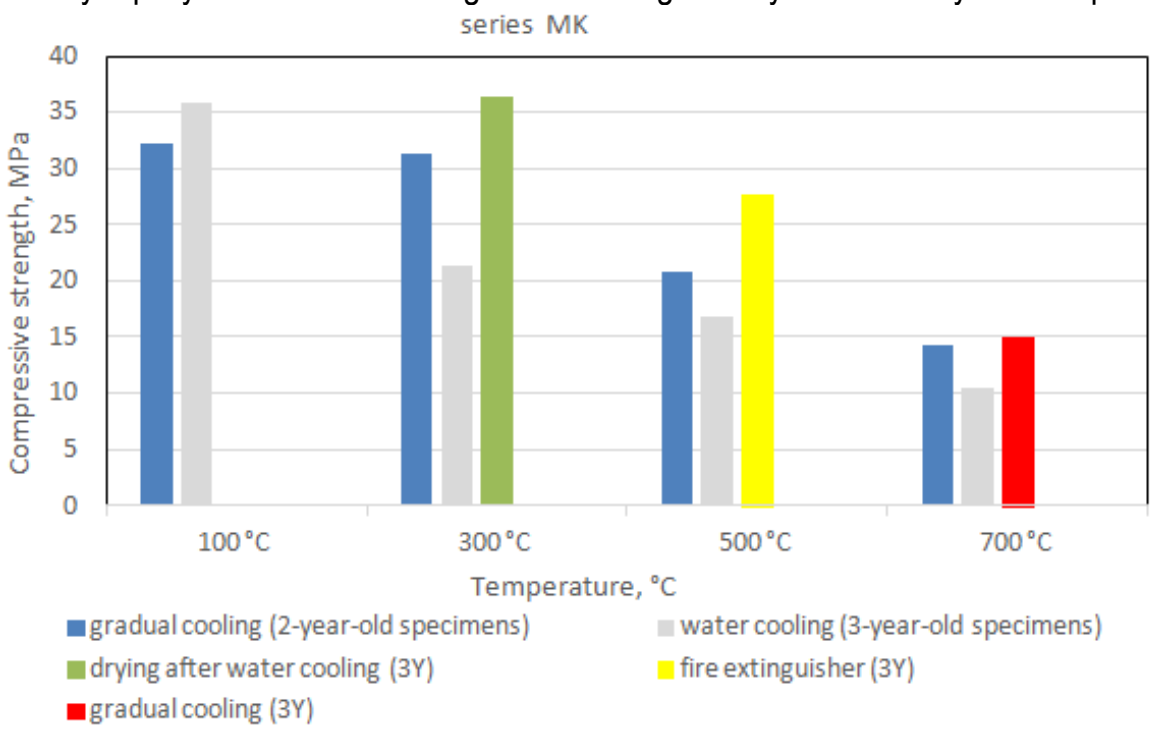

Figure 5 Effects of the cooling-method type and specimen age on the concrete mixture with metakaolin

Three specimens from the same series were heated to $500{ }^{\circ} \mathrm{C}$ and then exposed to fire-extinguishing dry powder. The powder did not reduce the concrete's temperature but only extinguished the fire. Here, the comparative results showed that the measured compressive strength of specimens cooled by air was $65 \%$ higher than those rapidly cooled by water and $33 \%$ higher than the gradually cooled two-year-old specimens. Similar to the procedure used for the two-year-old specimens, three specimens from the same series with metakaolin were gradually cooled after exposure to $700{ }^{\circ} \mathrm{C}$. The results showed a $5 \%$ higher residual compressive strength than that of the two-year-old specimens. This can be attributed to the positive influence of specimen age. The comparison of the strength of specimens exposed to dry powder with those rapidly cooled showed that the strength of the three specimens exposed to dry powder is $44 \%$ higher. Various cooling regimes were applied only on one test series to perceive the behavioral trend of the material and eventually present a new research avenue. Considering the test results and planned multiyear testing, other specimens have been retained for performing a five-year-old test. 
Influence of mixture design, age, and cooling regime on post-fire mechanical properties of lightweight self-compacted concrete

The comparison of the test results achieved in this study with those of the LWC given in EN 1994 1-2 showed that the results generally follow the same reduction trend for compressive strength. The series with microsilica showed a residual compressive strength below the values defined in Eurocode 4 for both cooling regimes. The recycled concrete mix showed similar behaviors with the exception at $500{ }^{\circ} \mathrm{C}$ for the five-year-old specimens. The lowest value for all four mixtures was achieved by the influence of water in the rapid cooling regime [12]. The critical temperature that shows values below those of EN $19941-2$ for the gradually cooled specimens is $700{ }^{\circ} \mathrm{C}$, regardless of the mixture type. The residual compressive strength was above the reference values in the cases of five-year-old metakaolin-based specimens and 2-year-old ground-clay specimens. The ground-clay specimens also showed better results in the case of the rapid cooling regime.

Figure 6 shows the influence of concrete-mix design on the residual compressive strength with respect to specimen age.
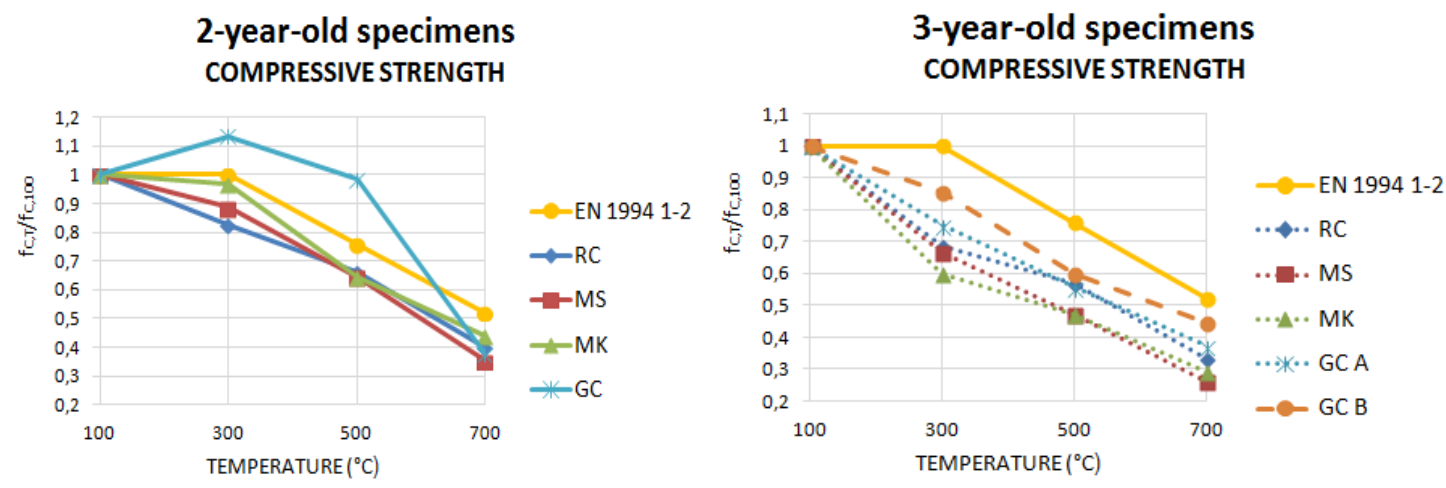

5-year-old specimens COMPRESSIVE STRENGTH

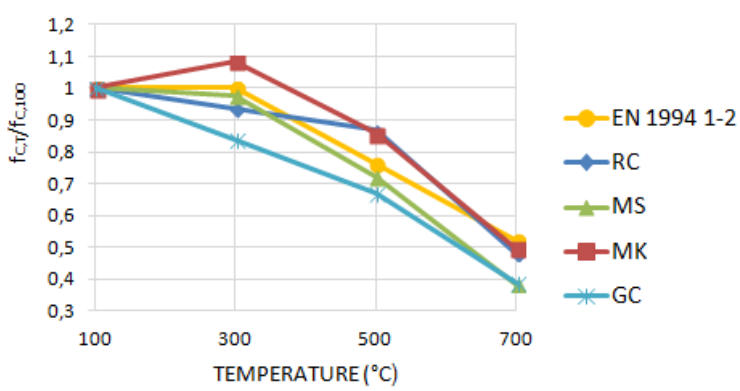

Figure 6 Comparison of residual compressive strength after fire exposure according to specimen age (comparison with EN 1994 1-2)

According to Fig. 6, the highest residual compressive strengths for the two-year-old specimens heated up to a temperature of $700{ }^{\circ} \mathrm{C}$ are observed for the concrete with ground clay. These results are much greater than those proposed by EN 1994-1-2 until the critical temperature of $500{ }^{\circ} \mathrm{C}$ is reached. In the case of the three-year-old specimens, the same mixture showed the highest compressive strength, regardless of the cooling regime. In the case of the five-year-old specimen, the best performance was displayed by the concrete with metakaolin. As shown, for the temperature of $700{ }^{\circ} \mathrm{C}$, with increase in specimen age, the results are closer to the values proposed by EN 1994 1-2. Nevertheless, mixtures of self-compacted LWC with microsilica and ground clay represent an exception with respect to the abovementioned effect.

\subsection{Dynamic modulus of elasticity}

The LWC is more brittle and has a lower modulus of elasticity than that of normal concrete [8]. The values of the modulus obtained directly from UPV were compared. The main factors affecting the modulus were determined to be the microcracks arising from the exposure of concrete to fire [7] and variations in the humidity of the 
Influence of mixture design, age, and cooling regime on post-fire mechanical properties of lightweight self-compacted concrete

specimens. The results of the rapidly and gradually cooled specimens differ in terms of the dynamic modulus of elasticity, such as compressive strength, which depends on air humidity throughout the test procedure. This is because the modulus is directly related to the specimen mass, which is increased owing to the presence of water. The reductions in the modulus values resulting from steady increase in the temperature are shown in Fig. 7. These modulus values are related to the reference value, namely the value obtained before the heating process. The recycled concrete and microsilica fillers have similar values, and their modulus of elasticity decreases with increasing temperature. The major decline is around $20 \%$ in the temperature range of $300-500{ }^{\circ} \mathrm{C}$. After the peak temperature of $700{ }^{\circ} \mathrm{C}$ is reached, $70 \%$ of the modulus value is lost. The rapid cooling regime resulted in approximately the same or lower values for the same fire temperatures relative to the gradually cooled specimens. The series with metakaolin showed slight differences than the previously analyzed mixtures; rapidly cooled specimens were observed to have a higher modulus than the gradually cooled specimens, although in a small percentage. This could be attributed to the weight gained by water absorption [13]. A decreasing trend of modulus is more evident in this mixture. Concrete with ground clay showed a minor variation in the modulus from 300 to $500{ }^{\circ} \mathrm{C}$ but also the largest decline compared with the reference modulus in case of gradual cooling in the furnace. The largest decrease in modulus was observed for the oldest specimens. The rapidly cooled specimens showed the largest distinction at $700{ }^{\circ} \mathrm{C}$, with the measured modulus showing a $20 \%$ higher value than other cooling regimes. Specimens with metakaolin, after heating to $300^{\circ} \mathrm{C}$ and then rapid cooling, were compared with re-dried specimens at $100{ }^{\circ} \mathrm{C}$. The repeated drying influenced the modulus of the specimens by exhibiting a lower modulus value by $31 \%$. This could be attributed to the occurrence of new microcracks in the concrete microstructure [12]. After exposure to fire at $500{ }^{\circ} \mathrm{C}$, the fire-extinguisher-based and gradual cooling schemes had a lower impact on the modulus of elasticity. The reduction is around $18 \%$ compared with the modulus obtained in the case of the rapid cooling scheme after heating to $500^{\circ} \mathrm{C}$.

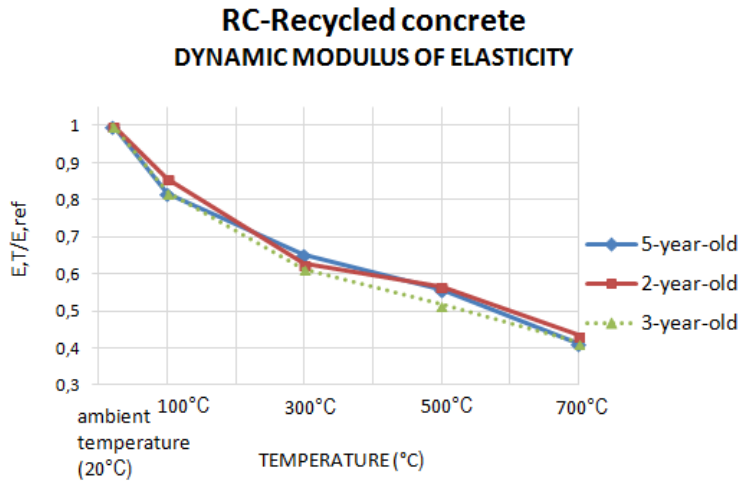

MK-Metakaolin DYNAMIC MODULUS OF ELASTICITY

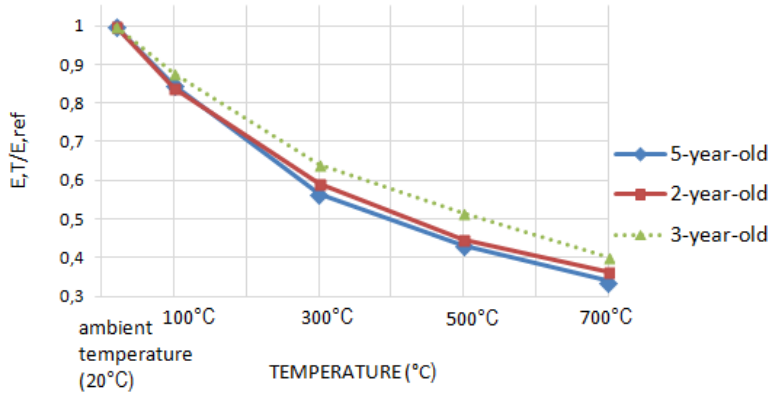

MC-Microsilica DYNAMIC MODULUS OF ELASTICITY

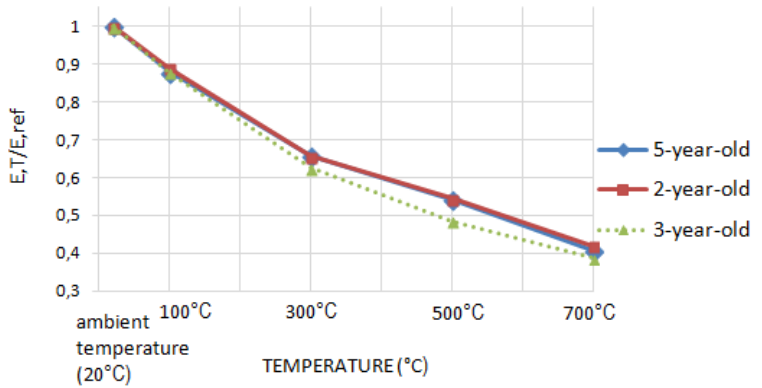

GC-Ground clay DYNAMIC MODULUS OF ELASTICITY

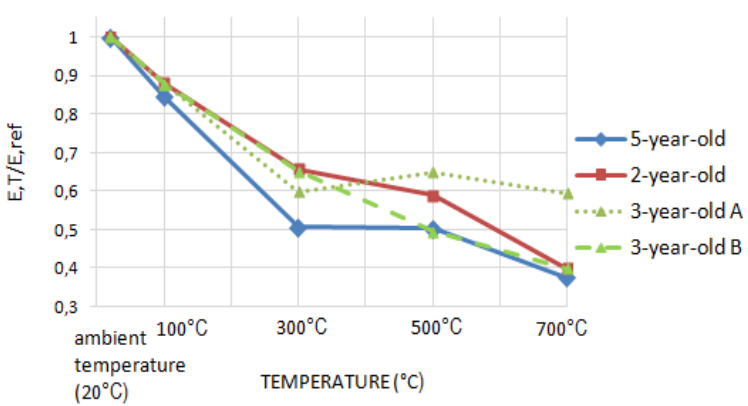

Figure 7 Reduction of dynamic modulus of elasticity with respect to specimen age

Unlike the compressive strength, the specimen age mainly does not affect the dynamic modulus of elasticity. The exception is the mixture with ground clay, for which the modulus, similar to strength, is lower. 
Influence of mixture design, age, and cooling regime on post-fire mechanical properties of lightweight self-compacted concrete

\subsection{Mass change}

Fig. 8 shows the change in the average mass of specimens, as it passes through its various stages of cooling or heating processes. The mass is reduced during the heating period, with applied pre-drying and subsequent heating, because of the loss of free and chemically bound water [12]. This effect is linearly related to the temperature. All four gradually cooled mixtures show relatively small mass loss up to $500{ }^{\circ} \mathrm{C}$. As the temperature increases above $500^{\circ} \mathrm{C}$, the loss of chemically bound water becomes significant. At $700{ }^{\circ} \mathrm{C}$, around $8 \%-14 \%$ of the reference mass is lost compared to the mass before the specimens were subjected to heating. Moreover, all four test series showed that the specimen age has negligible influence on residual mass.
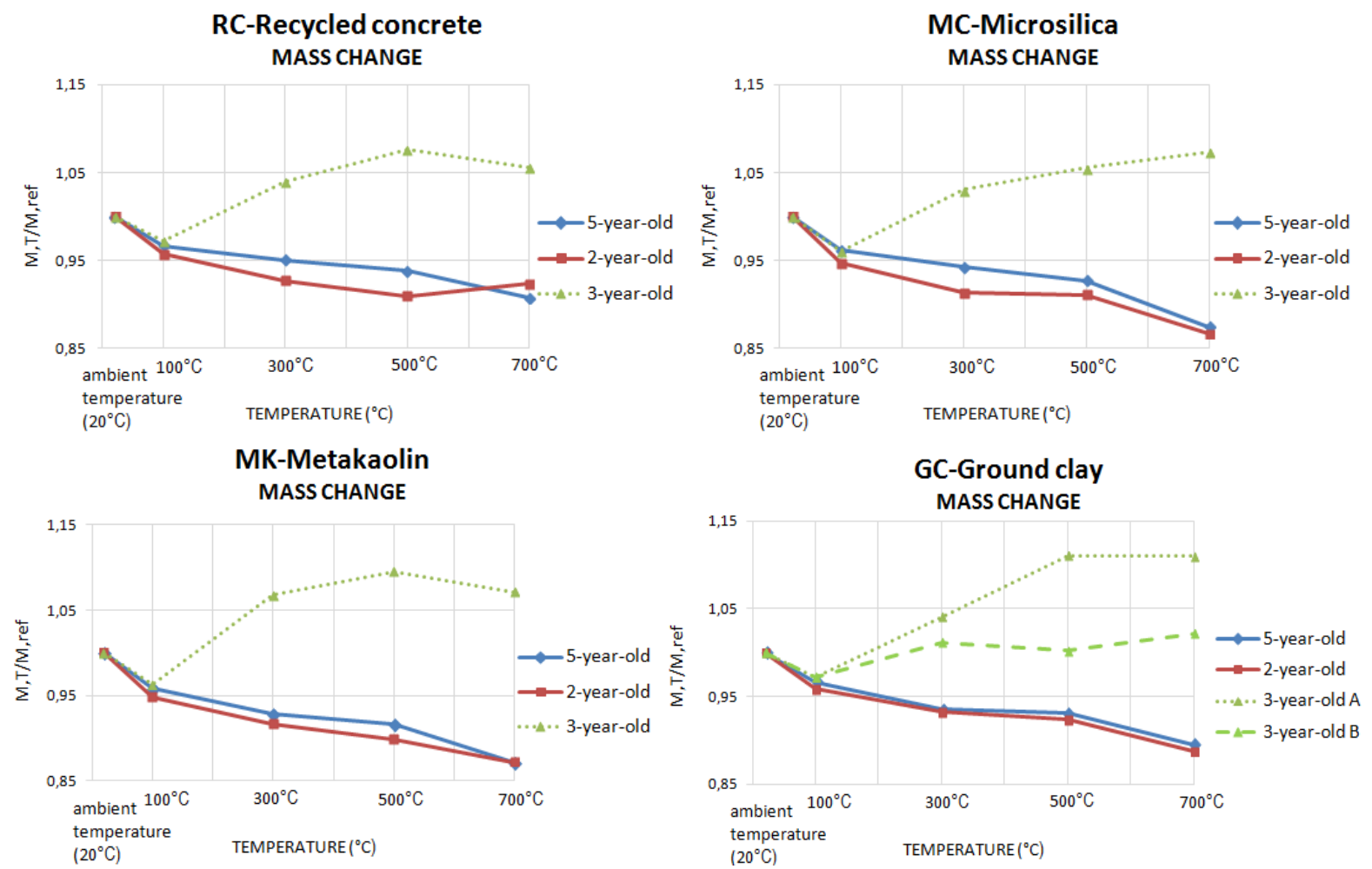

Figure 8 Change of specimen mass with respect to age

The rapid cooling of specimens caused evaporation of water on the contact surfaces and partial water absorption from the internal structure of concrete. Water saturation enhances the increase in mass by $10 \%$ within the whole temperature range. Post $24 \mathrm{~h}$, the rapidly cooled specimen showed a slightly lower mass than its mass measured immediately after cooling.

\section{CONCLUSIONS}

The degree of damage in a concrete structure after exposure to fire depends on the peak fire temperature, exposure time, composition of concrete, and moisture content. The purpose of this experiment was to determine residual mechanical properties of different mixtures of lightweight self-compacted concrete after its exposure to high temperatures. The results showed that the cooling method type and specimen age influence the compressive strength of concrete in the following way.

- Concrete age, in general, has a positive effect on residual compressive strength. The exception is concrete with ground clay filler; this mixture should be further examined with an emphasis on the problem of decreasing strength depending on time. 
Influence of mixture design, age, and cooling regime on post-fire mechanical properties of lightweight self-compacted concrete

- The concrete composition also influences the results. The comparison of relative compressive strengths showed that the best results were obtained by younger specimens of ground clay. For the testing of the five-yearold specimen, metakaolin appears to be the most suitable filler. In addition, the microsilica specimen achieved the lowest results. Therefore, it cannot be concluded which type of filler is the most optimal for this type of testing.

- The dynamic modulus of elasticity generally does not depend on the age of concrete; an exception to this is the concrete with ground clay.

- Water cooling has a negative impact on residual compressive strength. The most frequently observed concrete parameter, strength, is lower for the rapidly cooled specimen than the gradually cooled one. In addition, the compressive strength determined immediately after rapid cooling is higher than that determined $24 \mathrm{~h}$ after the rapid cooling process.

- The mass of concrete increases when cooled using water as the mass of absorbed water exceeds the water mass that evaporated in the drying process.

- $\quad$ From the perspective of mechanical properties, especially compressive strength, specimens exposed to elevated temperatures are convenient for treatment with extinguishing dry powder. This study shows that this type of fire extinguishment procedure is favorable.

\section{Acknowledgments}

This research is partially supported through project KK.01.1.1.02.0027, a project co-financed by the Croatian Government and the European Union through the European Regional Development Fund - the Competitiveness and Cohesion Operational Programme.

\section{References}

[1] Nguyen K.T.Q.; Ngo T.; Mendis P.; Heath D. 2017: Performance of high-strength concrete walls exposed to fire, Advances in Structural Engineering, 21 (8), pp. 1-10. https://doi.org/10.1177/1369433217732500

[2] Torić N.; Boko I.; Peroš B. 2011: Smanjenje mehaničkih svojstava betona velike čvrstoće, Građevinar, 63 (12), pp. 1033-1041.

[3] Pertiwi N.; Ahmad I.A.; Taufieq N.A.S. 2017: Analysis Residual Strength of Post Fire Concrete, Asian Journal of Applied Sciences, 5 (3), pp. 602-607.

[4] Balakrishnaiah D.; Balaji K.V.G.D.; Srinivasa Rao P. 2013: Study of mechanical properties of concrete at elevated temperatures-a review, IRJET: International Journal of Research in Engineering and Technology, 2 (8), pp. 317-328.

[5] Yu J.; Weng W.; Yu K. 2014: Effect of Different Cooling Regimes on the Mechanical Properties of Cementitious Composites Subjected to High Temperatures, The Scientific World Journal, Article ID 289213. https://doi.org/10.1155/2014/289213

[6] Li L.; Jia P.; Dong J.; Shi L.; Zhang G.; Wang Q. 2017: Effect of cement dosage and cooling regimes on the compressive strength of concrete after post-fire-curing from $800^{\circ} \mathrm{C}$, Construction and Building Materials, 142, pp. 208-220. https://doi.org/10.1016/j.conbuildmat.2017.03.053

[7] Torić N.; Boko I; Juradin S.; Baloević G. 2016: Mechanical properties of lightweight concrete after fire exposure, Structural Concrete 17 (6), pp. 1071-1081. https://doi.org/10.1002/suco.201500145

[8] Pavlić M. 2016: Mehanička svojstva samozbijajućeg lakog betona nakon izlaganja visokim temperaturama, Diplomski rad, Sveučilište u Splitu, Fakultet građevinarstva, arhitekture i geodezije, Split

[9] Schneider, U. 1995.: Compressive strength for service and accident conditions, Materials and Structures (28), pp. 410-414. https://link.springer.com/article/10.1007/BF02473077

[10] Bektas F.; Wang K.; Ceylan H. 2008: Use of Ground Clay Brick as a Pozzolanic Material in Concrete, Journal of ASTM International, 5 (10), pp. 1-10. https://doi.org/10.1520/JAl101681

[11] Beretin, M. 2017: Mehanička svojstva samozbijajućeg lakog betona sa dodatkom mljevene opeke nakon izlaganja visokim temperaturama, Završni rad, Fakultet građevinarstva, arhitekture i geodezije, Split

[12] Kokan T. 2017: Mehanička svojstva naglo hlađenog samozbijajućeg betona nakon izlaganja visokim temperaturama, Diplomski rad, Sveučilište u Splitu, Fakultet građevinarstva, arhitekture i geodezije, Split 
Influence of mixture design, age, and cooling regime on post-fire mechanical properties

of lightweight self-compacted concrete

[13] Križić B. 2018: Mehanička svojstva naglo hlađenog samozbijajućeg betona nakon izlaganja visokim temperaturama, Diplomski rad, Sveučilište u Splitu, Fakultet građevinarstva, arhitekture i geodezije, Split

Please cite this article as: Romić, A.; Juradin, S.; Boko, I.; Torić, N.: Influence of mixture design, age, and cooling regime on post-fire mechanical properties of lightweight self-compacted concrete, Electronic Journal of the Faculty of Civil Engineering Osijek-e-GFOS, 2020, 20, pp. 1-12, https://doi.org/10.13167/2020.20.1

Romić, A, Juradin, S, Boko, I, Torić, N 